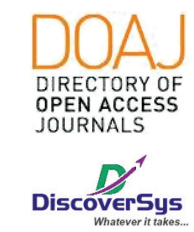

Published by DiscoverSys

\section{Perbedaan petanda osteoporosis dan inflamasi pada pasien diabetes melitus tipe 2 terkontrol dan tidak terkontrol}

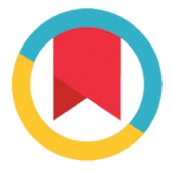

CrossMark

\author{
Emi Setianingsih, ${ }^{1 *}$ Imam Budiwiyono, ${ }^{2}$ Meita Hendrianingtyas ${ }^{2}$
}

\section{ABSTRACT}

Background: Prolonged hyperglycemia cause further complications in patients with Type 2 Diabetes Mellitus (T2DM). Examination of $\mathrm{HbA1c}$ as a glycemic control can determine the risk of complications. $\mathrm{N}$-Mid osteocalcin (N-Mid Oc) is used as a marker for early detection of osteoporosis. Increased neutrophil lymphocyte ratio (NLR) is a sign of simple inflammation that contributes to the progression and chronic complications in T2DM. The aim of the study is to analyze the differences between osteoporosis and inflammation markers in controlled and uncontrolled T2DM.

Methods: Analityc observational study with cross sectional approach was conducted in June - July 2019 involving 58 DMT2 patients at
Diponegoro National Hospital Semarang. The level of N-Mid Oc level were measured by ELISA method and NLR was measured by hematology analyzer, NLR values were obtained after manually calculated. Different test between research variables were using Mann-Whitney $\mathrm{U}$ test

Results: The median (min - max) N-Mid Oc levels of controlled and uncontrolled T2DM patients were $16.17(4.98-37.28) \mathrm{ng} / \mathrm{ml}$ and $12.29(3.54-37.28) \mathrm{ng} / \mathrm{ml}$ with a value of $\mathrm{p}=0.004$. Median (min - max) NLR of DMT2 patients controlled and uncontrolled were $1.82(0.64-3.94)$ and $2.41(1.08-6.46)$ with $p=0.007$.

Conclusion: There is a significant differences between N-Mid 0 level and NLR in controlled and uncontrolled T2DM patients.

Keywords: diabetes, neutrophil ratio, blood glucose, N-Mid Oc.

Cite This Article: Setianingsih, E., Budiwiyono, I., Hendrianingtyas, M. 2020. Perbedaan petanda osteoporosis dan inflamasi pada pasien diabetes melitus tipe 2 terkontrol dan tidak terkontrol. Intisari Sains Medis 11(2): 511-516. D0I: 10.15562/ism.v11i2.648

ABSTRAK

Latar belakang: Hiperglikemia berkepanjangan dapat menimbulkan komplikasi lebih lanjut pada pasien Diabetes Melitus Tipe 2 (DMT2). Pemeriksaan HbA1c sebagai kontrol glikemik dapat mengetahui risiko komplikasi. N-Mid osteocalcin (N-Mid Oc) dipakai sebagai salah satu petanda deteksi dini osteoporosis. Peningkatan neutrophil lymphocyte ratio (NLR) merupakan petanda inflamasi sederhana untuk memantau progresivitas dan komplikasi kronik pada DMT2. Tujuan dari penelitian ini adalah untuk membuktikan adanya perbedaan petanda osteoporosis dan inflamasi antara DMT2 terkontrol dan tidak terkontrol.

Metode: Penelitian observasional analitik dengan pendekatan belah lintang dilakukan pada bulan Juni - Juli 2019 melibatkan 58 pasien
DMT2 di Rumah Sakit Nasional Diponegoro Semarang yang memenuhi kriteria inklusi dan eksklusi. Pemeriksaan N-Mid Oc diperiksa dengan metode ELISA dan Pemerikasaan NLR menggunakan hematology analyser, nilai NLR didapatkan setelah dihitung secara manual. Uji beda antar variabel penelitian mengunakan Mann-Whitney U test's. Hasil: Median (min - maks) kadar N-Mid Oc pasien DMT2 terkontrol dan tidak terkontrol berturut-turut adalah 16,17 $(4,98-37,28) \mathrm{ng} / \mathrm{ml}$ dan $12,29(3,54-37,28) \mathrm{ng} / \mathrm{ml}$ dengan nilai $\mathrm{p}=0,004$. Median ( $\mathrm{min}-$ maks) NLR pasien DMT2 terkontrol dan tidak terkontrol berturut-turut adalah 1,82 (0,64-3,94) dan 2,41 (1,08-6,46) dengan nilai $p=0,007$. Simpulan: terdapat perbedaan bermakna dari N-Mid Oc dan NLR antara pasien DMT2 terkontrol dan tidak terkontrol.
'Residen Patologi Klinik Fakultas Kedokteran Universitas Diponegoro

2Staf Bagian Patologi Klinik Fakultas Kedokteran Universitas Diponegoro

${ }^{*}$ Correspondence to: Emi Setianingsih, Residen Patologi Klinik Fakultas Kedokteran Universitas Diponegoro dr.emilovely@gmail.com

Diterima: 19-10-2019

Disetujui: 09-07-2020

Diterbitkan: 01-08-2020
Kata kunci: diabetes, rasio neutrofil, gula darah, N-Mid Oc.

Cite Pasal Ini: Setianingsih, E., Budiwiyono, I., Hendrianingtyas, M. 2020. Perbedaan petanda osteoporosis dan inflamasi pada pasien diabetes melitus tipe 2 terkontrol dan tidak terkontrol. Intisari Sains Medis 11(2): 511-516. D0I: 10.15562/ism.v11i2.648

\section{PENDAHULUAN}

Diabetes melitus (DM) merupakan suatu penyakit metabolik yang ditandai dengan tingginya kadar gula darah (hiperglikemia) yang disebabkan oleh gangguan sekresi insulin, gangguan kerja insulin, atau kedua-duanya. ${ }^{1,2}$ Keadaan hiperglikemia yang berkepanjangan dapat menimbulkan komplikasi lebih lanjut pada pasien DM.1,2,3 Kementrian Kesehatan Republik Indonesia tahun 2018 melaporkan hasil Riset Kesehatan Dasar (Riskesdas) bahwa prevalensi DM di Indonesia rerata meningkat menjadi $2 \%$ diseluruh daerah Indonesia. $^{4}$ 
Prevalensi DM terbanyak saat ini yaitu diabetes melitus tipe 2 (DMT2) atau non insulin dependent diabetes mellitus (NIDDM) atau diabetes dengan onset dewasa, meliputi 90 - 95\% dari semua diabetes. ${ }^{5}$ Diabetes melitus tipe 2 yang diakibatkan oleh kondisi defisiensi insulin relatif, memerlukan pemantauan kontrol glikemik yang teratur. Kondisi hiperglikemi yang tidak terkontrol dapat menyebabkan kerusakan pada sistem tubuh dan menimbulkan komplikasi diantaranya meliputi makrovaskular dan mikrovaskular, maka penting dilakukan pemantauan kadar glukosa pada DMT2 yang optimal. ${ }^{6}$

Pemeriksaan HbAlc merupakan pemeriksaan laboratorium yang dianjurkan untuk pemantauan DMT2. HbA1c juga merupakan pemeriksaan tunggal yang baik untuk menilai resiko terhadap kerusakan jaringan yang disebabkan oleh tingginya kadar gula darah. Nilai HbAlc yang menjadi sasaran pengendalian DM sesuai rekomendasi adalah $<7 \%$, semakin tinggi nilai HbA1c maka semakin tinggi pula risiko komplikasi makrovaskular dan mikrovaskular pada DM..$^{3,4,7,8}$ American Diabetes Association (ADA) merekomendasikan bahwa kadar $\mathrm{HbAlc}$ dinyatakan terkontrol apabila berada $<7 \%$ dan tidak terkontrol jika $>7 \%{ }^{8}$

Komplikasi kronis DMT2 berupa penurunan kualitas tulang, hilangnya kekuatan tulang, peningkatan risiko fraktur dan gangguan penyembuhan tulang masih terus dipelajari., ${ }^{910}$ Penurunan kualitas tulang ditentukan oleh empat faktor penting yaitu densitas tulang (bone density), ukuran tulang, pergantian tulang (bone turnover) dan geometri tulang (mikroarsitektur). ${ }^{11}$ Osteokalsin (Osteocalsin/Oc) atau bone-GLA-protein (BGP) merupakan protein non kolagen dalam matriks tulang, yang berperan penting dalam proses mineralisasi dan bone turnover. Pemeriksaan Oc sering dipakai sebagai petanda awal untuk menilai proses pembentukan tulang cukup akurat. Metode pemeriksaan Oc adalah enzyme-linked immunosorbent assay (ELISA). ${ }^{12}$

Penelitian Öztürk et al. menunjukkan proses peradangan berperan penting dalam remodeling tulang dan patogenesis osteoporosis. Mereka melaporkan ada korelasi antara neutrophil lymphocyte ratio (NLR) dan skor osteoporosis (lebih tinggi pada pasien osteoporosis). ${ }^{13}$ Pemeriksaan neutrophil lymphocyte ratio (NLR) atau rasio limfosit netrofil adalah petanda inflamasi sederhana, tidak invasif, murah dan dapat diandalkan. ${ }^{14}$ Inflamasi pada DMT2 yang bersifat subklinis berperan terhadap progresivitas dan komplikasi kronik osteoporosis pada DMT2. ${ }^{15}$

Hubungan antara kontrol glikemik dan neutrophil lymphocyte ratio (NLR) pada pasien diabetes tipe 2 telah disimpulkan dalam penelitian oleh $\mathrm{Oh}$ et al (2016) dan Demirtas et al. (2015) Penelitian tersebut menyimpulkan bahwa NLR dapat digunakan sebagai petanda regulasi dan komplikasi diabetes selama terapi, dimana peningkatan kontrol glikemik Hba1c yang buruk pada pasien DMT2 juga dapat meningkatkan nilai NLR. ${ }^{15,16,17}$ Penelitian ini bertujuan untuk membuktikan perbedaan petanda osteoporosis $\mathrm{N}-\mathrm{Mid} \mathrm{Oc}$ dan inflamasi NLR antara pasien DMT2 terkontrol dan tidak terkontrol.

\section{METODE PENELITIAN}

Penelitian ini merupakan penelitian observasional analitik dengan pendekatan belah lintang (cross sectional). Waktu penelitian dikerjakan pada bulan Juni - Juli 2019. Sampel penelitian adalah penderita dengan riwayat DMT2 dan memeriksakan diri di RS Nasional Diponegoro Semarang yang dipilih secara non random, yang bersedia ikut dalam penelitian ini dan menandatangani informed consent serta memenuhi kriteria inklusi dan eksklusi. Pengambilan subjek penelitian dilakukan secara consecutive sampling, Sampel diambil sampai memenuhi jumlah sampel minimal Sampel penelitian dibagi menjadi dua kelompok yaitu individu DMT2 yang terkontrol dan tidak terkontrol. Kelompok kontrol berdasarkan kadar $\mathrm{HbAlc}$, pasien DMT2 dengan HbA1c $<7 \%$ termasuk kedalam kelompok DMT2 terkontrol, sedangkan pasien DMT2 dengan HbA1c > 7\% termasuk kedalam kelompok pasein DMT2 tidak terkontrol.

Sampel penelitian ini adalah sebagian atau mewakili populasi yang diteliti yang memenuhi kriteria inklusi dan eksklusi. Kriteria inklusi dalam penelitian ini (1) Penderita DMT2, (2) suhu tubuh normal (suhu $36,5-37,2^{\circ} \mathrm{C}$ ), (3) kadar ureum normal, (4) kadar SGPT (serum glutamic pyruvic transaminase) normal. Kriteria eksklusi dalam penelitian ini adalah (1) anemia, nilai normal hemoglobin untuk pria: $13,5-17,5 \mathrm{~g} / \mathrm{dl}$; wanita: $11,5-15,5 \mathrm{~g} / \mathrm{dl}$, (2) kelainan hematologi, (3) terapi kortikosteroid, (4) perokok dan peminum alkohol.

Pemeriksaan $\mathrm{N}-\mathrm{Mid}$ Oc dilakukan di laboratorium GAKI (gangguan akibat kekurangan iodium) Fakultas Kedokteran Universitas Diponegoro, sedangkan pemeriksaan hematologi rutin dan HbAlc, dan dilakukan di laboratorium Rumah Sakit Nasional Diponegoro (RSND). Pemeriksaan HbA1c rujukan RSND yaitu Laboratorium Klinik Prodia Semarang.

Pemeriksaan NLR Hasil perhitungan manual perbandingan antara jumlah netrofil absolut dengan jumlah limfosit absolut. Jumlah netrofil absolut dan jumlah limfosit absolut diperiksa menggunakan alat hematology analyzer dengan metode 
perhitungan dan diferensiasi berdasarkan saluran optik atau impedance. Parameter HbAlc diperiksa dengan metode HPLC, sedangkan untuk pemeriksaan N-Mid Osteocalsin menggunakan metode Enzyme-linked immunosorbent assay (ELISA).

\section{Analisis data}

Data yang dikumpulkan meliputi wawancara, pemeriksaan laboratorium. Data yang terkumpul dilakukan editing, coding, dan dianalisis secara komputerisasi. Analisis data meliputi analisis deskriptif dan uji hipotesis. Analisis univariat dilakukan terhadap masing-masing variabel untuk mengetahui karakteristik sampel. Analisis bivariat dilakukan untuk mencari perbedaan N-Mid osteocalsin dan NLR pada pasien DMT2 terkontrol dan tidak terkontrol.

Data yang diperoleh sebelum dilakukan analisis perbedaan dilakukan terlebih dahulu uji normalitas data dengan uji Shapiro-Wilk. Data berdistribusi normal dilanjutkan uji beda dua kelompok tidak berpasangan (independent $t$-test). Apabila distribusi datanya tidak normal dilakukan transformasi data dan diolah dengan Mann-Whitney U test. Dianggap bermakna bila p£0,05 dengan tingkat kepercayaan/ Confidence Interval (CI) sebesar 95\%.

\section{HASIL DAN PEMBAHASAN}

Hasil skrinning didapatkan 89 pasien yang terdiri dari 58 pasien DMT2 tidak terkontrol dan 31 DMT2 terkontrol. Dua puluh sembilan pasien DMT2 tidak terkontrol dan dua pasien DMT2 terkontrol memiliki kadar hemoglobin yang rendah sehingga dikeluarkan dari penelitian, sehingga didapatkan jumlah pasien DMT2 terkontrol sebanyak 29 sampel dan 29 sampel untuk pasien DMT2 yang tidak terkontrol.

Data karakteristik subyek penelitian pada kedua kelompok digambarkan pada tabel 1. Hasil pada tabel 1 tampak jenis kelamin pada subyek penelitian pasien DMT2 terkontrol dan tidak terkontrol. Subyek penelitian DMT2 terkontrol terdiri laki laki sebanyak 12 orang $(41,4 \%)$ dan perempuan sebanyak 17 orang $(58,6 \%)$. Jumlah subjek penelitian DMT2 tidak terkontrol pun sama dengan DMT2 terkontrol terdiri dari laki - laki sebanyak 12 orang $(41,4 \%)$ dan perempuan sebanyak 17 orang $(58,6 \%)$.

Rerata umur subyek penelitian pasien DMT2 terkontrol adalah $63,28 \pm 10,49$ tahun, sedangkan rerata umur subyek penelitian DMT2 tidak terkon-

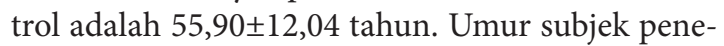
litian DMT2 terkontrol termuda berusia 34 tahun dan tertua 74 tahun, sedangkan DMT2 tidak terkontrol termuda berusia 37 tahun dan tertua 79 tahun.

Median IMT subyek penelitian pasien DMT2 terkontrol adalah $25,04 \mathrm{~kg} / \mathrm{m}^{2}$, sedangkan median IMT pasien DMT2 tidak terkontrol adalah $25,6 \mathrm{~kg} / \mathrm{m}^{2}$. Data karakteristik kedua kelompok DMT2 ini berdasarkan Departemen Kesehatan RI tergolong dengan berat badan yang gemuk untuk laki-laki $(23-27 \mathrm{~kg} / \mathrm{m} 2)$ dan untuk perempuan yaitu $(25-27 \mathrm{~kg} / \mathrm{m} 2) .{ }^{18}$ Median nilai hemoglobin $(\mathrm{Hb})$ pasien DMT2 terkontrol dan $\mathrm{Hb}$ pasien DMT2 tidak terkontrol adalah $12,9 \mathrm{~g} / \mathrm{dl}$. Data karakteristik ini menunjukkan bahwa nilai Hemoglobin $(\mathrm{Hb})$ keduanya masih dalam rujukan normal untuk pria $(13,5-17,5 \mathrm{~g} / \mathrm{dl})$ dan untuk wanita yaitu $(11,5-$ $15,5 \mathrm{~g} / \mathrm{dl})$. Median leukosit pasien DMT2 terkontrol

Tabel 1 Data karakteristik subyek penelitian

\begin{tabular}{|c|c|c|c|c|c|}
\hline \multirow[b]{3}{*}{ Variabel } & \multicolumn{4}{|c|}{ Kelompok } & \multirow[b]{3}{*}{$p$} \\
\hline & \multicolumn{2}{|c|}{ Diabetes Melitus Terkontrol } & \multicolumn{2}{|c|}{ Diabetes Melitus Tidak Terkontrol } & \\
\hline & Rerata \pm SB & Median (min; maks) & Rerata \pm SB & Median (min; maks) & \\
\hline \multicolumn{6}{|l|}{ Demografis } \\
\hline Umur (tahun) & $63,28 \pm 10,49$ & $55,9(34-74)$ & $55,90 \pm 12,04$ & $60,5(37-79)$ & $0,016^{*}$ \\
\hline \multicolumn{6}{|l|}{ Jenis kelamin } \\
\hline Laki-laki & \multicolumn{2}{|c|}{$12(41,4 \%)$} & \multicolumn{2}{|c|}{$12(41,4 \%)$} & \\
\hline Perempuan & \multicolumn{2}{|c|}{$17(58,6 \%)$} & \multicolumn{2}{|c|}{$17(58,6 \%)$} & 1,000 \\
\hline IMT $\left(\mathrm{kg} / \mathrm{m}^{2}\right)$ & $25,07 \pm 10,49$ & $25,04(18,13-35,09)$ & $25,03 \pm 3,96$ & $25,6(16,23-31,97)$ & 0,586 \\
\hline \multicolumn{6}{|l|}{ Hematologi } \\
\hline $\mathrm{Hb}(\mathrm{gr} / \mathrm{dL})$ & $12,95 \pm 1,42$ & $12,9(11,5-16,00)$ & $13,03 \pm 1,16$ & $12,9(11,5-15,60)$ & 0,801 \\
\hline Leukosit $\left(\times 10^{3} / \mu \mathrm{L}\right)$ & $6,90 \pm 1,41$ & $6,70(4,20-8,90)$ & $8,01 \pm 2,05$ & $7,70(4,00-13,00)$ & $0,020^{*}$ \\
\hline NLR & $1,93 \pm 0,90$ & $1,82(0,64-3,94)$ & $2,58 \pm 1,03$ & $2,41(1,08-6,46)$ & $0,007^{\star}$ \\
\hline$N-\operatorname{Mid} O c(n g / m l)$ & $17,36 \pm 7,78$ & $16,17(4,98-37,28)$ & $12,04 \pm 7,20$ & $12,29(3,536-37,280)$ & $0,004^{*}$ \\
\hline
\end{tabular}


$\left(6,70 \times 10^{3} / \mu \mathrm{L}\right)$ dan tidak terkontrol $\left(7,70 \times 10^{3} / \mu \mathrm{L}\right)$, nilai rujukan leukosit adalah $\left(3,6-11 \times 10^{3} / \mu \mathrm{L}\right)$ sehingga nilai leukosit dalam kedua kelompok masih dalam batas normal.

\section{Kadar $\mathbf{N}$-mid osteocalcin serum}

Perbedaan kadar $\mathrm{N}$-mid osteocalcin serum pada pasien DMT2 terkontrol dan tidak terkontrol seperti pada tabel 2. Data hasil N-mid osteocalcin walaupun sudah dilakukan tes uji normalitas transformasi data data tidak terdistribusi normal $(\mathrm{p}<0,05)$, sehingga dilakukan uji dengan uji Mann Whitney. Hasil analisis menunjukkan adanya perbedaan kadar $\mathrm{N}$-mid osteocalcin pada pasien DMT2 terkontrol dan tidak terkontrol $(\mathrm{p}=0,004)$.

Distribusi data kadar $\mathrm{N}$-mid osteocalcin serum pada pasien DMT2 terkontrol dan tidak terkontrol tampak pada gambar 1.

Hasil penelitian ini menunjukkan kadar $N$-mid osteocalcin serum pada pasien DMT2 terkontrol lebih tinggi jika dibandingkan dengan DMT2 yang tidak terkontrol. Perbedaan ini bermakna secara statistik $(p=0,004)$. Hal ini sesuai dengan hipotesis peneliti, dimana pada hipotesis disebutkan terdapat perbedaan antara $\mathrm{N}$-mid osteocalcin serum pada pasien DMT2 terkontrol dan yang tidak terkontrol. N-mid osteocalcin pada sejumlah penelitian saja menunjukkan perbedaan antera pasien DM dengan kontrol non DM. ${ }^{10,19}$ Starup et al. tahun 2014 mengungkapkan bahwa Oc signifikan lebih rendah pada pasien DM, hal ini dikarenakan perubahan pada bone turnover. ${ }^{20}$

Pasien DMT2 dengan bone turnover berkurang sering dihubungkan dengan risiko komplikasi fraktur dikarenakan keadaan resistensi insulin dan aktivitas fisik rendah, semuanya dapat berperan dalam perkembangan penyakit tulang pada diabetes. Hiperglikemia dapat secara langsung mempengaruhi osteoklas dan osteoblas selain mempengaruhi osteosit. Efek hiperglikemia menghambat diferensiasi sel punca mesenkim menyebabkan hipermineralisasi dan gangguan resorpsi matriks mineral, yang dapat berkontribusi penyakit tulang pada pasien DMT2. Hiperglikemia memicu hipermineralisasi pada tulang yang menyebabkan kepadatan mineral tulang (BMD) tinggi dan berkurangnya bone turnover menyebabkan microcracks dan fraktur. ${ }^{20,21}$

Beberapa penelitian tentang Oc berhubungan negatif dengan glukosa darah puasa, insulin puasa, HbA1c dan HOMA-IR. ${ }^{22,23-26}$ Penelitian ini menunjukkan bahwa pada DMT2 yang tidak terkontrol, kadar Oc serum menurun dapat disebabkan oleh peningkatan resistensi insulin dan peningkatan aktivitas enzim lisosom. Penurunan kadar penanda turnover tulang akibat penghambatan fungsi osteoblastik yang diinduksi oleh hiperglikemia. Konsentrasi serum Oc dapat bermanfaat untuk memantau tindak lanjut perubahan tulang pada diabetes mellitus tipe 2. Penelitian lain juga didapatkan tingginya kadar $\mathrm{HbAlc}$ telah dikaitkan dengan peningkatan risiko patah tulang pada pasien dengan diabetes. ${ }^{20}$

\section{Nilai neutrophil lymphocyte ratio (NLR)}

Perbedaan nilai neutrophil lymphocyte ratio (NLR) pada pasien DMT2 terkontrol dan tidak terkontrol seperti tampak pada tabel 3.

Distribusi data neutrophil lymphocyte ratio (NLR) pada pasien DMT2 terkontrol dan tidak terkontrol tampak pada gambar 2.

Hasil penelitian ini menunjukkan neutrophil lymphocyte ratio (NLR) serum pada pasien DMT2 tidak terkontrol lebih tinggi jika dibandingkan dengan DMT2 terkontrol. Perbedaan ini bermakna secara statistik $(p=0,007)$. Hal ini sesuai dengan hipotesis peneliti, dimana pada hipotesis disebutkan terdapat perbedaan antara nilai neutrophil

Tabel 2 Perbedaan kadar $\mathbf{N}$-mid osteocalcin serum pada pasien DMT2 terkontrol dan tidak terkontrol

\begin{tabular}{lccc}
\hline Kelompok & N & $\begin{array}{c}\text { Kadar } \boldsymbol{N} \text {-mid osteocalcin (ng/ml) } \\
\text { Median (Min-Maks) }\end{array}$ & $\boldsymbol{p}$ \\
\hline Pasien DMT2 terkontrol & 29 & $16,17(4,98-37,28)$ & $0,004^{\ddagger \star}$ \\
Pasien DMT2 tidak terkontrol & 29 & $12,29(3,54-37,28)$ & \\
\hline
\end{tabular}

Keterangan: ${ }^{*}$ Signifikan $(\mathrm{p}<0,05) ;{ }^{*}$ Mann Whitney

Tabel 3 Perbedaan neutrophil lymphocyte ratio (NLR) pada pasien DMT2 terkontrol dan tidak terkontrol

\begin{tabular}{llcc}
\hline Kelompok & N & NLR Median (Min-Maks) & $\boldsymbol{p}$ \\
\hline Pasien DMT2 terkontrol & 29 & $1,82(0,64-3,94)$ & $0,007^{\ddagger *}$ \\
Pasien DMT2 tidak terkontrol & 29 & $2,41(1,08-6,46)$ & \\
\hline
\end{tabular}

Keterangan: ${ }^{*}$ Signifikan $(\mathrm{p}<0,05) ;{ }^{*}$ Mann Whitney 


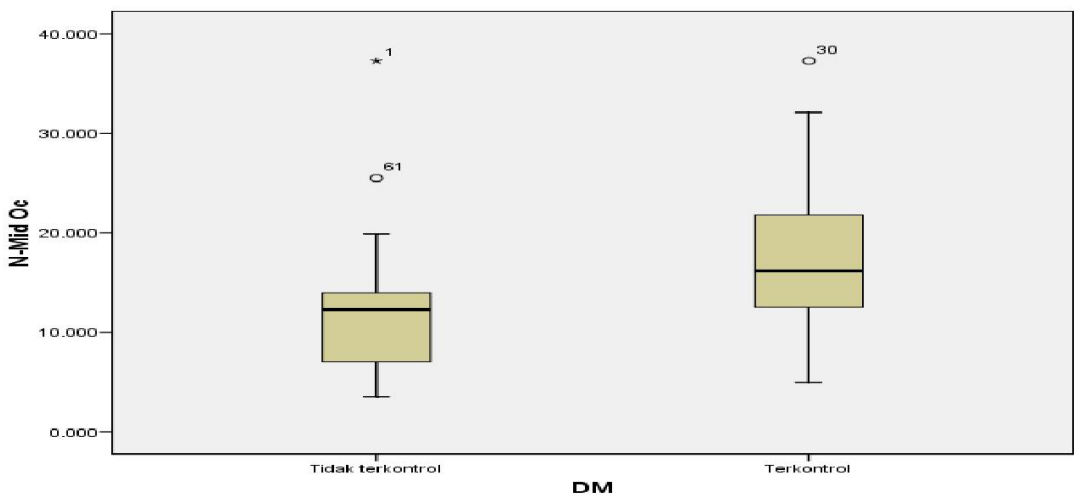

Gambar 1 Grafik box plot kadar N-Mid osteocalcin (N-Mid O) serum dalam satuan $\mathrm{ng} / \mathrm{ml}$ pada pasien DMT2 terkontrol dan tidak terkontrol

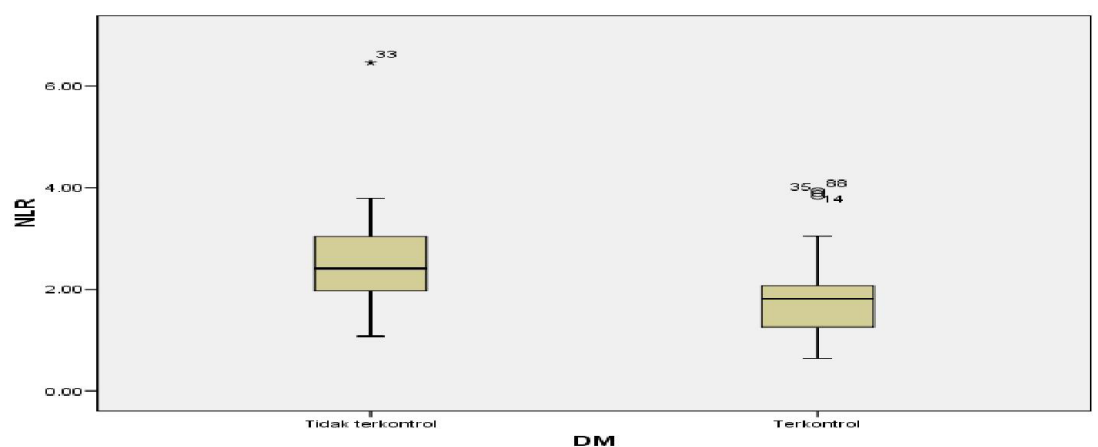

Gambar 2 Grafik boxplot neutrophil lymphocyte ratio (NLR) serum pada pasien DMT2 terkontrol dan tidak terkontrol

lymphocyte ratio (NLR) pada pasien DMT2 tidak terkontrol dan terkontrol.

Kontrol glikemik HbA1c bisa digunakan sebagai petanda faktor risiko komplikasi mikro dan makrovaskular pada diabetes, control glikemik yang baik bisa memprediksi inflamasi dan komplikasi terkait diabetes yang sedang berlangsung. ${ }^{14}$ Penelitian ini menunjukkan NLR pada pasien tidak terkontrol lebih tinggi, hal ini sejalan dengan penelitian yang telah dilakukan oleh Shiny et al. dan Lou et al., NLR berperan pada intoleransi glukosa dan resistensi insulin pada pasien diabetes tipe $2 .{ }^{15,27}$ Penelitian serupa juga dikemukan oleh Demirtas et al. menunjukkan hubungan antara kontrol glikemik dan indeks hematologi pada pasien diabetes tipe 2 dan menyimpulkan bahwa NLR dapat digunakan sebagai penanda regulasi dan komplikasi diabetes selama masa tindak lanjut pasien diabetes. ${ }^{17}$ Pasien diabetes terkait komplikasi mikrovaskular menunjukkan NLR memiliki penanda prediktif yang dapat diandalkan dari nefropati diabetik tahap awal, retinopati dan ulkus kaki diabetik. Peningkatan NLR adalah prediktor kejadian kardiovaskular utama pada pasien DMT2. ${ }^{22}$

Penelitian ini menunjukkan bahwa NLR bukan penanda inflamasi saja tetapi NLR membantu menilai tingkat kontrol glikemik untuk memprediksi bahwa pasien dengan diabetes kontrol buruk kemungkinan akan mengalami komplikasi yang progresif di masa depan. Hiperglikemia dengan kontrol glikemik yang buruk akan meningkatkan faktor inflamasi berkaitan dengan peningkatan IL-6,IL-18 dan TNF-a, yang efeknya merusak vaskular. Hiperglikemia juga meningkatkan pembentukan ROS menyebabkan aktivasi faktor transkripsi, faktor pertumbuhan dan mediator sekunder. Melalui cedera jaringan secara langsung atau aktivasi mediator sekunder ini, akan memicu stress oksidatif dan kerusakan jaringan. ${ }^{28}$

Penelitian ini tidak membedakan jenis kelamin dan faktor - faktor yang dapat mempengaruhi keadaan osteoporosis sebelum penelitian (diet, lamanya terdiagnosisnya DMT2, riwayat penggunaan terapi, riwayat defisiensi estrogen, vitamin D dan kadar kalsium serta aktifitas fisik subyek penelitian). Jenis kelamin pria memiliki tulang yang lebih tebal dan besar, begitu pula usia bisa mempengaruhi massa tulang terkait usia secara bertahap dan berkelanjutan. Lamanya terdiagnosis DMT2 dan kontrol glikemik pasien sebelum ikut penelitian akan mempengaruhi hasil pemeriksaan $\mathrm{N}$-Mid Oc. Hiperglikemia yang berkepanjangan akan mempengaruhi kadar AGE's dan ROS, hal ini akan mempengaruhi bone turnover dan bone mineralisation.

\section{SIMPULAN DAN SARAN}

Sebagai kesimpulan, penelitian kami menunjukkan bahwa terdapat perbedaan yang bermakna $\mathrm{N}$-Mid Oc dan NLR antara pasien DMT2 terkontrol dan tidak terkontrol. Penelitian ini bersifat cross sectional Perlu dilakukan penelitian lebih lanjut dengan populasi DMT2 sesuai dengan pengelompokkan usia dan jenis kelamin yang sama. Pengelompokan pasien berdasarkan waktu terdiagnosis dan terapi pengobatan yang sama perlu dipertimbangkan.

\section{ETIKA DALAM PENELITIAN}

Penelitian dilakukan setelah mendapat ethical clearance dari Komisi Etik Penelitian Kesehatan Fakultas Kedokteran Universitas Diponegoro dengan No.274/EC/KEPK/FKUNDIP/VII/2019 tanggal 1 Juli 2019.

\section{KONFLIK KEPENTINGAN}

Peneliti menyatakan tidak terdapat suatu konflik kepentingan terkait publikasi dari artikel ini. 


\section{PENDANAAN}

Penelitian ini tidak mendapat dana hibah dari pemerintah ataupun sector swasta lainnya.

\section{DAFTAR PUSTAKA}

1. Sudoyo AW, Setiyohadi B, Alwi I, K. MS, Setiati S. Buku ajar ilmu penyakit dalam. Jakarta: Pusat Penerbit Ilmu Penyakit Dalam; 2014.

2. Hadisaputro S, Setyawan H. Epidemiologi dan faktorfaktor risiko terjadinya diabetes mellitus tipe 2 . Semarang: Penerbit Universitas Diponegoro; 2007: p.133-54.

3. Rudijanto A, Yuwono A, Shahab A, Manaf A, Pramono B. Konsensus pengelolaan dan pencegahan diabetes melitus Tipe 2 di Indonesia. Jakarta: PB PERKENI; 2015.

4. Badan penelitian dan pengembangan kesehatan kementerian kesehatan RI. Riset kesehatan dasar. Jakarta: 2013.

5. American Diabetes Association. Diagnosis and classification of diabetes mellitus. Standar of Medical Care In Diabetes 2018:41:562-9.

6. International Diabetes Federation. IDF diabetes atlas. 8th ed; 2017.

7. World Health Organization. Use of Glycated Haemoglobin (HbAlc) in the Diagnosis of Diabetes Mellitus. Geneva; 2011.

8. American Diabetes Association. Diagnosis and classification of diabetes melitus. Diabetes Care. 2012;35:64-71.

9. Carlos M, Luyten FP, Bart VS, Greet K, Katleen V. The impact of type 2 diabetes Front Endocrinol (Lausanne). 2018;6:1-17.

10. Starup LJ. Diabetes mellitus biochemical markers of bone turnover, diabetes control, and Bone. Front Endocrinol (Lausanne). 2013;4:1-17.

11. Priyana A. Peran pertanda tulang dalam serum pada tatalaksana osteoporosis. Univ med. 2007;26:152-9.

12. Halimah E, Rositawati W, Pratiwi I. N-MID Osteocalsin $(\mathrm{N}-\mathrm{MID}$ Oc) dan $\beta$-Crosslaps ( $\beta$-CTx) sebagai penanda biokimia Bone Turn Over pada wanita menopause. IJCP. 2016;5:67-74.

13. Öztürk ZA. Inverse relationship between neutrophil lymphocyte ratio (NLR) and bone mineral density (BMD) in elderly people. Arch Gerontol Geriatr. 2013;57:81-5.

14. Hussain M, Babar MZM, Akhtar L, Hussain MS. Neutrophil lymphocyte ratio (NLR): A well assessment tool of glycemic control in type 2 diabetic patients. Pak J Med Sci. 2017;33:1366-70.

15. Lou M, Luo P, Tang R, Peng Y, Yu S, Huang W. Relationship between neutrophil-lymphocyte ratio and insulin resistance in newly diagnosed type 2 diabetes mellitus patients. BMC Endocr Disord. 2015;15:9.

16. Oh Y, Kwon GC, Koo SH, Kim J. Association between glycemic control and hematolical indices in type 2 diabetic patients. Lab Med Online. 2016;6:134-9.
17. Demirtas L, Degirmenci H, Akbas EM, Ozcicek A, Timuroglu A, Gurel A, et al. Association of hematological indices with diabetes, impaired glucose regulation and microvascular complications of diabetes. Int J Clin Exp Med. 2015;8:11420-7.

18. Lee JS, Kim NY, Na SH, Youn YH, Shin CS. Reference values of neutrophil-lymphocyte ratio, lymphocyte-monocyte ratio, platelet lymphocyte ratio, and mean platelet volume in healthy adults in south korea. Med (Baltimore). 2018;97:26-31.

19. Badan Penelitian dan Pengembangan Kesehatan Kementerian Kesehatan RI. Hasil utama riset kesehatan dasar 2018. Jakarta: Kemenkes; 2018.

20. Starup-Linde J, Hygum K, Langdahl BL. Skeletal fragility in type 2 diabetes mellitus. Endocrinol Metab (Seoul). 2018;33(3):339-51.

21. Salindeho A., Mulyadi, Rottie J. Pengaruh senam diabetes mellitus terhadap kadar gula darah penderita diabetes melitus tipe 2 di sanggar senam persadia kabupaten gorontalo. 2016;4:12-18.

22. Wang Q, zhang B, Xu Y, Xu H, Zhang N. The Relationship between serum osteocalsin concentration and glucose metabolism in patients with type 2 diabetes mellitus. J Endocrinology. 2013;2:1-7.

23. Räkel, Sheehy O, Rahme E,LeLorier J. Osteoporosis among patients with type 1 and type 2 diabetes. J Diabet. 2008;22:193-205.

24. Kindblom JM, Ohlsson C., Ljunggren O.. Plasma osteocalcin is inversely related to fat mass and plasma glucose in elderly Swedish men. J Bone and Mineral Research. 2009:21:785-91.

25. Im JA, Yu BP, Jeon JY, KimSH. Relationship between osteocalcin and glucose metabolism in postmenopausal women. Clinica Chimica Acta. 2008;22:66-9.

26. Yeap BB, Chubb SAP. Reduced serum total osteocalcin is associated with metabolic syndrome in older men via waist circumference, hyperglycemia, and triglyceride levels. J Endocrinology. 2010;12:265-72.

27. Shiny A, Bibin YS, Shanthirani CS, Regin. Association of neutrophil-lymphocyte ratio with glucose intolerance: an indicator of systemic inflammation in patients with type 2 diabetes. Diabetes Tech Ada. 2014;12:524-30.

28. Roy B. Biomolecular basis of the role of diabetes mellitus in osteoporosis and bone fractures. W J Diabetes. 2013;12:101-13.

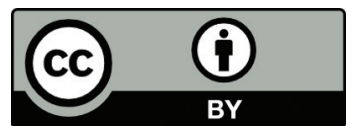

This work is licensed under a Creative Commons Attribution 